Lebedev, S.V. (2020). The problem of ethnic identity in the modern world: how the "national spirit" manifests itself in folk art. 21 st century: history and modernity of art. Collection of Scientific Articles. European Scientific e-Journal, 4 (4), 5-13. Hlučín-Bobrovníky: “Anisiia Tomanek” OSVČ.

$\Lambda$ ебедев, С.В. (2020). Проблема этнической идентичности в современном мире: как в народном

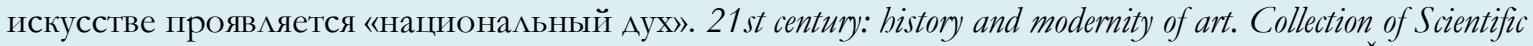
Articles. European Scientific e-Journal, 4 (4), 5-13. Hlučín-Bobrovníky: “Anisiia Tomanek” OSVČ.

DOI: $10.47451 /$ art2020-12-004

EOI: $10.11244 / \operatorname{art} 2020-12-004$

The paper is published in Crossref, Internet Archive, Google Scholar, Academic Resource Index ResearchBib, JGate, ISI, CiteFactor, ICI, eLibrary databases.

Sergey $V$. Lebedev

Full Professor, Doctor of Philosophical Sciences Head of the Department of Philosophy Higher School of Folk Arts (Academy) St Petersburg, Russia E-mail: servicleb@list.ru

\title{
The problem of ethnic identity in the modern world: how the "national spirit" manifests itself in folk art
}

\section{Abstract:}

The article is devoted to the problem of preserving Russian ethnic identity. In the era of globalization, the identity of many countries is experiencing a crisis. A manifestation of national identity is the traditional folk art of an ethnic group. It is in him that what is called the spirit of the people is manifested. In modern conditions in Russia, it is not only necessary to preserve the Russian culture, but also to raise it to a new height. To achieve this, it is necessary to change the curricula of schools and universities, which can help the experience of teaching a course on historical ethnology of Russia to the students of the Higher School of Folk Arts. The author concludes that Historical Ethnology of Russia in combination with the disciplines of History and Philosophy allows preparing a highly qualified art critic, who is ready and able to solve the tasks that his professional activity sets him.

\section{Keywords:}

identity, globalization, ethnos, folk art.

\section{Сергей Викторович Аебедев}

профессор, Аоктор философских наук., зав. кафелрой философии Высшая школа народных искусств (Академия) Санкт-Петербург, Россия E-mail: servicleb@list.ru 


\section{Проблема этнической иАентичности в современном мире: как}

в народном искусстве проявияется «национацьный Аух»

\section{Aннотачия:}

Статья посвящена проблеме сохранения русской этнической идентичности. В эпоху глобализации илентичность многих стран переживает кризис. Проявлением национальной идентичности явцяется опирающееся на традиции народное искусство этноса. Именно в нем прояв яяется то, что называется духом народа. В современных условиях в России не только необходимо сохранить русскую культуру, но и поднять на новую высоту. Что бы этого Аобиться, необходимы изменения учебных программ школ и вузов, в чём может помочь опыт преподавания курса, посвященного исторической этнологии России, студентам ВШНИ. Автор приходит к выводу, что историческая этнология России в сочетании с Аисциплинами истории и философии позволяет подготовить высококвалифицированного искусствоведа, готового и способного решать задачи, которые ставит перед ним его профессиональная деятельность.

\section{Kлючевые слова:}

идентичность, глобализация, этнос, народное искусство.

\section{Introduction}

The era of globalization has created a crisis of ethnic identity, which, paradoxically, is combined with the development of many new identities. The importance of preserving ethnic identity is constantly emphasized by many political and public figures. So, in the speech of the President of Russia V.V. Putin at the Valdai International Discussion Forum on September 19, 2013, pointed out the objective need to "search for a new strategy and preserve their identity in a radically changing world, in a world that has become more open, transparent, and interdependent", in which "in one or another form almost all countries, all peoples collide: Russian, European peoples, Chinese, Americans, and society from almost all countries of the world" (The meeting of the international discussion club Valdai, 2013).

\section{1.}

The term "identity", which derived from two similar Latin concepts idem, i.e., "the same", and identifico, i.e., "identify", appeared in ancient logic (Culture as a factor of modernization of Russia: Collective monograph, 2015). So, initially designated relationship, the members of which are absolutely identical to each other (Lebedev, 2018). In philosophy, "identity" was considered as a category, used as a synonym for the words "completely similar", "identical", "identical". Paradoxically, the concept of "identity" became especially widely used after the publication in 1968 
of the book Identity: Youth and Crisis written by the German psychologist E. Erikson. In this classic work, the author described a state that he called "an identity crisis". Thus, scientists first discussed the identity crisis, and only then gave clear formulations of the concept (Semenenko, 2017). in the social sciences, the concept of 'identity' came from the works of the French historical school "annals", which studies the mentality of historical epochs. Currently, without the use of the concept of "identity", it is impossible to imagine any scientific work on psychology, pedagogy, history, ethnology, etc. In this regard, today there is a wide range of scientific definitions of identity.

In the human psyche, identity is the property of most fully expressing how an individual imagines his belonging to social groups and communities - social, national, professional, linguistic, political, religious, racial and others (Ahmedkhanova, 2015). Simply put, identity is what the individual relates to and considers himself to be. Identity is one of the most important essential characteristics of a society, which reflects and expresses the peculiarities of world perception and the nature of cognition of the existence of an individual and the groups, to which he belongs.

The identity can exist in two scales of perception. The very first level of identity is the individual ("I am identity"). In other words, "I am identity" is our idea of ourselves as an individual. at the same time, "I am identity" is also how we realize the continuity of our being in the world. The second, higher social level, is manifested in the perception of how other individuals recognize me, that is, my real existence and my personal social status in this society. According to the famous American social thinker C. Huntington, identity can be defined as the self-consciousness of an individual, and at the same time also of the groups to which an individual belongs. moreover, individuals acquire identity and change it only as part of a group (Huntington, 2004).

There can be an unlimited number of self-identifications that any individual can choose. It should single out only the most important groups of individual identities. It is necessary first to point out the so-called ascriptive-literally "prescribed", i.e., those, over which individuals have no power, predetermined independently of the individual (Lebedev, 2018). Ascriptive identities include age, gender, physical characteristics of the body, blood relationship, race and ethnicity.

Many other identities - ethnic, social, etc. - can be attributed to the identities acquired by the individual. In particular, it is possible to note such ethnic identities as a clan, tribal, ethnic, linguistic, religious, territorial. Social identities - the social status of an individual, the awareness of belonging to a certain part of society - play an ever-increasing role in the life of society in modern conditions. Then the 
individual and the group are aware of such identities as a class and civilizational affiliation. Territorial identities - hometown, region, country - can be also distinguished.

Political identities play a huge role in the life of society. These include shared ideology, electoral behaviour (voting for specific parties and organizations), membership in a political party, participation in public activities, loyalty or opposition to the existing government, etc.

Finally, in the self-consciousness of both the individual and society as a whole, special economic identities are always present and often dominate among other identities - education, profession, position, labour collective, income level, economic needs, the relationship of oneself with a certain class and social group; etc. (Lebedev, 2018).

Thus, the identity of a person is largely determined by the individual himself (with excep for only the ascriptive). However, what determines all other identities? Identity defines society, but identity is based on the dominant culture of a given society in a given historical period of time (Lebedev, 2018).

Each country and each nation are based and exist on its own specific national identity, based on traditional religion, native language, common historical memory and historical traditions. Finally, national identity is largely determined by folk art. So, national culture, understood in the broad sense of the word, is the basis of national identity (Lebedev, 2018). Under the term "national" in this article will be considered as a synonym for "ethnic".

An ethnos is understood as an inter-generational blood-related community of people who have common stable features of language, culture, psyche, selfconsciousness and territory that have historically developed in a certain territory (Leontiev, 1998), i.e., an understanding of their difference from other communities and their own unity. So, an ethnos is a phenomenon that is simultaneously biological, social, geographical, cultural and spiritual, based on a common culture and having a unique identity.

What is meant by national identity? It should be noted that the main factors of the development of ethnicity are:

- territorial collectivity (the cohabitation of the majority ethnic group in a certain area, or the presence of certain "historical homeland");

- the belief in a common ethnic origin ethnic group from a common ancestor;

- cultural unity (community of language, religion, universally accepted interpretation of national history, the accepted social norms of behaviour); 
- the unity of the total business (economic) activities;

- awareness of shared historical fate;

- a common opposition to the "other".

All these factors basically create the nation and national consciousness. Here is how the classic of sociology, a prominent American scientist of Russian origin P.A. Sorokin figuratively wrote, "Paraphrasing the words of Archimedes, it can be said that give me these factors, and I will create a variety of nations for you, starting from the disenfranchised Sudras, i.e., representatives of the lower castes of India and ending with full-fledged Brahmins.” (Sorokin, 2006).

Of course, in our time in a number of countries, there are acute ideological crises caused by the problem of identity, e.g., in Austria, the inhabitants of which cannot decide whether they are Germans or any particular nation, the debate about Austrian identity has been going on for decades. After Austria acceded to the European Union, the state began to spread a "pan-European" identity. It is no accident that the famous Austrian writer Robert Menasse called his essay on modern Austria as $A$ Country Without Properties, paraphrasing the title of the novel $A$ Man Without Properties, written by the Austrian writer Robert Musil in the late 1930s. In the end, R. Menasse came to the conclusion that Austria is devoid of any purely Austrian identity. According to him, "public opinion polls confirm that, apart from abstract information about one's own nationality, no one can really explain what the homeland is for Austrians." (Menasse, 1999)

There is even more difficult problem of the national identity in a country like Canada, i.e., English Canada, populated by immigrants of various but mostly nonBritish origin, since Quebec, French Canada. On the contrary, they have their own French-Canadian identity. Due to history and geography, it is difficult to speak of any Anglo-Canadian identity at all. It is no coincidence that there is an aphorism that Canada has a lot of geography, but little history and no culture at all.

Canada has always been a country of immigrants, and among the people who moved to this sparsely populated Great Britain's dominion, people of non-Britain origin predominated. Since the 1960s, the majority of immigrants in Canada have been non-Europeans, mostly of non-Christian faith, who grew up in traditional tribal and clan societies. At the same time, in Canada, unlike the United States, there was almost no "melting pot", and the ethnic, racial and religious groups of the country did not merge into a single whole. It is significant that even in the 1991 census, only $2.8 \%$ of the country's residents called themselves simply 'Canadians'. The rest clearly 
identified themselves as Canadians of British, French, German, Ukrainian and other origins. $26.9 \%$ of Canadians are classified as "other" by statistics.

However, in Canada, where the concept of 'multiculturalism' was born in the 1970 s, in our time, the multiplicity of different identities has led to the disappearance of identities as such. In October 2015, current Prime Minister of Canada (since 2015) Justin Trudeau told The New York Times Magazine (NYT) "There is no core identity in Canada, there is no mainstream. There are common values such as openness, respect, compassion, the desire to work hard, support each other, and seek equality and justice. These qualities make us the first post-national state." (Justin Trudeau, 2015) Thus, Canada can consider itself a country, in which there is not and cannot be a state-forming nation. Accordingly, there is no decisive core of the national culture.

However, still, Canada is an exception to the rule. Basically, the world is dominated by the ideas of national development. They can mean both self-criticisms on the verge of self-flagellation and a sense of national superiority. However, in general, it is a sense of national identity that determines the behaviour of an ethnic group.

\section{3.}

What are the characteristic features of Russian identity that fundamentally distinguish it from the ethnic identities of many ethnic groups? The peculiarities of Russian identity are because Russia is not just a country, but an independent unique civilization. Russian Slavophiles wrote about this in the 19th century, and their main provisions on the multiplicity of civilizations in the last century were picked up by such Western thinkers as A. Toynbee, O. Spengler, S. Huntington, etc. These authors agreed that Russian identity is a civilizational identity just as Western European peoples are characterized by a sense of belonging to a single Western European civilization.

A manifestation of national identity is the traditional folk art of an ethnic group. It is in him that what is called the "spirit of the people" manifests itself. Russian folk art is one of the most significant manifestations of the "Russian spirit". Russian iconography, wood and bone carvings, the works of Russian jewelers, lacquer miniatures and embroidery, lace and paintings on fabric and wood can be seen as a manifestation of the primordial Russianness. The beauty of Russian folk art is not abstract - it is a manifestation of the norm of life of a particular people.

According to the academician, the president of the Higher School of Folk Arts V.F. Maksimovich, "traditional arts and crafts is one of the most important elements 
of the cultural 'gene pool' of Russia, as it assumes the function of protecting national identity in the context of globalization, the wide spread of products of mass culture that generates and accumulates a cultural memory of generations. Authentic works of folk art have always played an important role in the education of patriotic feelings of a person, contributed to the preservation of national identity and the identity of national cultural life" (Maksimovich, 2018).

Among the features of Russian ethnic identity, it can also be noted that Russia, unlike Western European states, was originally formed as a multi-ethnic state and, as researchers note, "Russia's multiculturalism is its generic quality" (Culture as a factor of modernization of Russia, 2015). Because of this, Russian culture is at the same time all-Russian, "its own", native to all the peoples of historical Russia.

Therefore, ethnic identity is incomplete without folk art. The existence of folk art is evidence of the health of the people. Under these conditions, the growing interest in traditional art forms is quite understandable. It should be noteed that, according to the academician, the president of the Higher School of Folk Arts V.F. Maksimovich, "traditional arts and crafts is a myriad of spiritual, moral, aesthetic, technological and material wealth, which is so full of open soul and nature of man, his view of the world, ideas and dreams, history, relations with other Nations." (Maksimovich, 2013).

According to V.F. Maksimovich and S.V. Lebedev, the most important obstacle to the further development of folk art is that it is not done by professionals. For the development of folk art, including its new forms, so that national art is not limited only to the restoration of old techniques and products, it is necessary to give higher education to artists, which is the mission of the Higher School of Folk. Arts as a state university.

For thousands of years, traditional applied art has been based on the practical experience of masters, based on the examples of their ancestors. However, in our time, this is not enough. A modern artist should also be an all-round personality. Then his knowledge, experience and work will give excellent shoots (Lebedev \& Maksimovich, 2015).

\section{4.}

Russian traditional applied art remains an integrating factor of Russian identity in the new century. The crisis of identity in the era of globalization only increases the importance of traditional art. In Russia of the 21 st century, it is necessary to raise the value and prestige of folk culture. Of course, this will require changes in school and 
university programmes, in which it is necessary to strengthen the national and cultural component.

Two centuries ago, the great German philosopher J.G. Fichte drew attention to the need to educate national feelings. He noted that "... The means of salvation... consists in the formation of a completely new self, which existed before, perhaps, only as an exception in individuals, but never as a universal and national self, and in the education of a nation whose past life has faded and has become an appendix to another's life, which will either belong exclusively to it, or, if it should extend from it to others, will remain intact and; in a word: what I propose as a means of preserving the existence of the German nation is a complete change in education." (Fichte, 2009)

The creation of the Higher School of Folk Arts - the world's first higher educational institution that trains cadres of artists of traditional art, was evidence that in the modern history of Russia, the state began to support folk art. Thus, the staff of the Higher School of Folk Arts contributes not only to the direct training of future artists of traditional applied art, but also to the strengthening of Russian ethnic identity.

The Department of Philosophy of the Higher School of Folk Arts has developed an educational and methodological complex of the discipline Historical Ethnology of Russia. The purpose of this discipline is to describe the complex of factors that have a decisive impact on the cultural, social and even political life of the country. This course will help students of the Academy, future artists of traditional applied art, to understand the peculiarities of the ethnic and political development of Russia, which have had a direct impact on the nature of Russian folk art.

Historical Ethnology of Russia has been taught at the Higher School of Folk Arts since 2007 following the educational standard for the specialty 50.03.04 Theory and History of Arts in the 2 nd year (the 3 rd semester). The total labour intensity of the discipline is 2 credits, 72 academic hours. This discipline is studied by art historians only. The course is not taught to bachelors and painters, although they also need to study the peculiarities of the ethnic and cultural development of the Russian people and other nationalities of the country. the author has developed a textbook Historical Ethnology of Russia. Textbook for Students of Educational Institutions Studying in the Direction of Training "Decorative and Applied Arts and Crafts". As it can be seen, the opportunities to teach this course to bachelors and painters are already ready.

\section{Conclusion}


Historical Ethnology of Russia in combination with the disciplines of History and Philosophy allows preparing a highly qualified art critic, who is ready and able to solve the tasks that his professional activity sets him.

Those, who have attended the discipline Historical Ethnology of Russia, as shown by the results of control measures (tests, tests, essays), possess the basic facts of the ethnic history of Russia, are freely guided in the variety of modern ethnological concepts and are able to apply their knowledge to the analysis of modern social development. Thus, the experience of teaching historical ethnology can be considered positive.

\section{References:}

Ahmedkhanova, S.M. (2015). The formation of national identity. Young Scientist, 14, 438-441.

The meeting of the international discussion club Valdai (2013, September 19). Retrieved November 18, 2019 from http://www.kremlin.ru/news/19243

Culture as a factor of modernization of Russia: Collective monograph (2015). Ed. 2nd. Moscow: Publishing House of the Moscow Humanitarian University.

Lebedev, S.V. (2018). Glocalization and the return of ethnicity in the age of globalization. World of Science, Culture, and Education, 2 (69), 257-261.

Lebedev, S.V., Maksimovich, V.F. (2015). Russian North: historical and ethnocultural features of the formation of the Russian region. The People and Culture, 6, 28-63.

Leontiev, A.A. (1998). Cultures and languages of the peoples of Russia, CIS and the Baltic States. Moscow.

Maksimovich, V.F. (2018). Education of children and youth by means of traditional arts and crafts in the educational practice of the higher school of folk arts. Pedagogy of Art, 1.

Maksimovich, V.F. (2013). Ways of updating professional education in traditional applied art. Issues of Cultural Studies, 8.

Menasse, R. (1999). A country without properties: an essay on Austrian self-consciousness. St Petersburg: Petersburg - the 21 st Century.

Semenenko, I.S. (2017). Category of identity in social sciences: concept, cognitive potential, research priorities. Identity: Personality. Society. Politics. Encyclopedic Edition. Moscow: Ves Mir.

Sorokin, P.A. (2006). Social and cultural dynamics. Moscow: Astrel.

Fichte, J.G. (2009). Speeches to the German nation. St Petersburg: Nauka. 
Huntington, S. (2004). Who are we? Challenges of the American national identity. Moscow: AST, Transitbook.

Justin Trudeau: Canada in General is the first post-national state in which there is no place for any basic identity (2015, December 13). Retrieved June 11, 2020 from https://www.nytimes.com/2015/12/13/magazine/trudeaus-canadaagain.html 